\title{
Effect of continental shelf canyons on phytoplankton biomass and community composition along the western Antarctic Peninsula
}

\author{
M. T. Kavanaugh ${ }^{1, *}$, F. N. Abdala ${ }^{2}$, H. Ducklow ${ }^{3}$, D. Glover ${ }^{1}$, W. Fraser ${ }^{4}$, \\ D. Martinson ${ }^{5}$, S. Stammerjohn ${ }^{6}$, O. Schofield ${ }^{7}$, S. C. Doney ${ }^{1}$ \\ ${ }^{1}$ Marine Chemistry and Geochemistry Department, Woods Hole Oceanographic Institution, MS 25, 266 Woods Hole Road, \\ Woods Hole, Massachusetts 02543, USA \\ ${ }^{2}$ Ecologia de Fitoplâncton e Microorganismos Marinhos, Federal University Rio Grande, Brazil \\ ${ }^{3}$ Earth and Environmental Sciences, Lamont Doherty Earth Observatory, Columbia University, Palisades, New York 10964, USA \\ ${ }^{4}$ Polar Oceans Research Group, Sheridan, Montana 59749, USA \\ ${ }^{5}$ Division of Ocean and Climate Physics, Lamont Doherty Earth Observatory, Columbia University, Palisades, \\ New York 10964, USA \\ ${ }^{6}$ Institute of Arctic and Alpine Research, University of Colorado, Boulder, Colorado 80309, USA \\ ${ }^{7}$ Institute of Marine and Coastal Sciences, Rutgers University, Rutgers, New Jersey 08901, USA
}

\begin{abstract}
The western Antarctic Peninsula is experiencing dramatic climate change as warm, wet conditions expand poleward and interact with local physics and topography, causing differential regional effects on the marine ecosystem. At local scales, deep troughs (or canyons) bisect the continental shelf and act as conduits for warm Upper Circumpolar Deep Water, with reduced seasonal sea ice coverage, and provide a reservoir of macro- and micronutrients. Shoreward of many canyon heads are Adélie penguin breeding colonies; it is hypothesized that these locations reflect improved or more predictable access to higher biological productivity overlying the canyons. To synoptically assess the potential impacts of regional bathymetry on the marine ecosystem, 4 major canyons were identified along a latitudinal gradient west of the Antarctic Peninsula using a highresolution bathymetric database. Biological-physical dynamics above and adjacent to canyons were compared using in situ pigments and satellite-derived sea surface temperature, sea ice and ocean color variables, including chlorophyll a $(\mathrm{chl}$ a) and fucoxanthin derived semi-empirically from remote sensing reflectance. Canyons exhibited higher sea surface temperature and reduced sea ice coverage relative to adjacent shelf areas. In situ and satellite-derived pigment patterns indicated increased total phytoplankton and diatom biomass over the canyons (by up to 22 and $35 \%$, respectively), as well as increases in diatom relative abundance (fucoxanthin:chl a). While regional heterogeneity is apparent, canyons appear to support a phytoplankton community that is conducive to both grazing by krill and enhanced vertical export, although it cannot compensate for decreased biomass and diatom relative abundance during low sea ice conditions.
\end{abstract}

KEY WORDS: Western Antarctic Peninsula - Canyons - Phytoplankton · Diatoms · Remote sensing $\cdot$ Adélie penguin habitat $\cdot$ Sea ice

\section{INTRODUCTION}

The western side of the Antarctic Peninsula (WAP) is experiencing some of the most dramatic climate change on the planet (IPCC AR4; Trenberth et al.

\footnotetext{
${ }^{*}$ Corresponding author: mkavanaugh@whoi.edu
}

2007), with rapid ocean and atmosphere warming (Vaughan et al. 2003, Meredith \& King 2005, Martinson et al. 2008), melting of coastal glaciers (Vaughan 2006), and reductions in seasonal sea ice cover (Stammerjohn et al. 2012, Turner et al. 2012). Over

(C) The authors 2015. Open Access under Creative Commons by Attribution Licence. Use, distribution and reproduction are unrestricted. Authors and original publication must be credited. 
the past half century, both air and sea temperatures have risen in response to regional and global forcing, with a $6^{\circ} \mathrm{C}$ increase in average wintertime air temperature (e.g. Ducklow et al. 2012), a $1^{\circ} \mathrm{C}$ increase in sea surface temperature (SST) (Meredith \& King 2005), and a $0.7^{\circ} \mathrm{C}$ increase in subsurface ocean temperature attributed to both ocean warming and changes in ocean circulation (Martinson et al. 2008, Martinson 2012). Changes in regional wind patterns and seasonal ice-ocean feedbacks have led to a decline in the duration of seasonal sea ice cover by nearly $90 \mathrm{~d}$ since the beginning of satellite-based measurements in 1979 (Stammerjohn et al. 2008, 2012). Multi-scale repercussions are evident throughout the marine ecosystem as warmer conditions expand poleward and interact with local physics and topography (Ducklow et al. 2007).

How interannual and seasonal changes in sea ice affect ecosystem productivity along the WAP is complex, with likely non-linear responses of phytoplankton productivity to decreased sea ice coverage. Antarctic coastal waters exhibit high rates of primary production (100-200 $\mathrm{g} \mathrm{C} \mathrm{m}^{-2} \mathrm{yr}^{-1}$ ) during a limited growing season of about 150-180 d (Smith et al. 1998, Vernet et al. 2008, Ducklow et al. 2012). These high rates are often observed along the retreating sea ice edge in spring, where there are ample macronutrients and water column stability, the latter influencing light availability (Mitchell \& Holm-Hansen 1991). These conditions allow for large diatom-dominated blooms that support short food chains, consisting of diatoms, krill, and apex predators (Huntley et al. 1991). With atmospheric warming, large areas $\left(\sim 24 \times 10^{3} \mathrm{~km}^{2}\right)$ of shallow coastal systems that are newly open following extensive sea ice loss may allow for increased biomass, estimated at $9.1 \times 10^{5} \mathrm{t}$ of carbon (Peck et al. 2010). Analyses of 3 decades of satellite and in situ chlorophyll a ( $\mathrm{chl}$ a) data along the WAP shelf suggest that phytoplankton biomass has increased in the central WAP at Marguerite Bay, but decreased in the northern WAP north of Anvers Island (Montes-Hugo et al. 2009). Latitudinal trends reflect reduced seasonal sea ice cover as well as increased cloud formation and winds in the north. Decreased biomass in the northern WAP is also associated with substantial decreases in primary production (12-50\%; Vernet et al. 2008). Finally, phytoplankton (Montes-Hugo et al. 2009) and food-web structure (Sailley et al. 2013) may shift with continued reductions in sea ice cover, with dominance by smaller phytoplankton and increased microbial recycling in regions where seasonal sea ice formation is minimal.
Submarine canyons can locally influence both horizontal and vertical ocean circulation patterns and nutrient availability, which in turn affect phytoplankton dynamics (e.g. Allen et al. 2001, Ryan et al. 2005) and subsequent distribution and diversity of higher trophic levels (Cunha et al. 2011, Fanelli et al. 2011). Canyon dynamics along some regions of the Antarctic continental margin may be affected both by latitudinal trends in atmospheric warming and sea ice loss, as well as regional shifts in winds and ocean circulation. Along the Amundsen and Bellinghausen Seas, the southern boundary of the Antarctic Circumpolar Current (ACC) is not spatially separated by the presence of a large subpolar gyre (like in the Weddell and Ross Seas) but abuts the continental shelf (Nitsche et al. 2007, Clarke et al. 2012, Martinson 2012). Upper Circumpolar Deep Water (UCDW) is found in the mid-level ACC and is characterized by a vertical maximum in potential temperature, low dissolved oxygen, and relatively high macro- and micronutrient concentrations (Hofmann et al. 1996, Meredith \& King 2005, Martinson et al. 2008). While wind-driven upwelling and internal tides have been hypothesized as important transport mechanisms for UCDW onto the continental shelf (Wallace et al. 2008), recent modelling studies (e.g. Dinniman et al. 2011, St. Laurent et al. 2013) and observations (Martinson \& McKee 2012) demonstrate that interactions between the ACC and canyon mouths on the shelf-slope break are also important factors in the shoreward movement of UCDW. Canyons along the WAP and Amundsen continental shelves may facilitate the delivery of nutrients and heat to coastal surface waters, which can directly and indirectly affect phytoplankton dynamics (Smith et al. 1998, Schofield et al. 2013) through changes in physiological rates or changes in the onset or duration of the growing season. Some studies have postulated positive effects of UCDW intrusions on phytoplankton (e.g. Prézelin et al. 2000, $2004)$; intrusions of UCDW may dilute high levels of macronutrients found on continental shelves (Serebrennikova \& Fanning 2004).

Evidence from in situ studies over the Palmer Deep, south of Anvers Island $\left(\sim 64.94^{\circ} \mathrm{S}, 64.42^{\circ} \mathrm{W}\right)$, suggests enhanced productivity of planktonic ecosystems above the canyon compared with adjacent shallow areas (Ducklow et al. 2013, Oliver et al. 2013, Schofield et al. 2013). Adélie penguins from breeding colonies in the Palmer region forage almost exclusively in and/or near canyons (Oliver et al. 2013). The Adélie's major food source, krill, tends to aggregate in the canyon with the long harmonic of the semi-diurnal tide (27 d; Bernard \& Steinberg 2013). Glider surveys 
revealed increases in chl a concentration in the canyon, particularly where warmer temperatures invade the surface layers (Schofield et al. 2013). These observations (from Palmer Deep) support 3 interconnected hypotheses regarding the ecological roles of canyon dynamics along the WAP. Canyons act as conduits for UCDW, which can (1) reduce seasonal sea ice cover and increase access to open water areas for foraging by top predators, both during the initial breeding season in spring as well as over the winter sea ice period; (2) provide a reservoir of relatively high macro- and micronutrients year-round; and (3) deliver warmer water, which can directly and indirectly affect biological production by affecting physiological processes and water column stratification.

Understanding how these local process studies extend to the entire WAP or throughout the season is limited by the lack of synoptic observations inherent in ship based in situ sampling (as noted by Prézelin et al. 2004). Synoptic satellite-based efforts have focused on regional-scale or larger-scale processes along the WAP (e.g. Smith et al. 2008, Montes-Hugo et al. 2009, Peck et al. 2010, Cimino et al. 2013), with high cloud cover and lack of topographical detail limiting analyses at higher space/time resolution. No studies to date have focused on local dynamics at seasonal or finer scales. Using a multi-year record of pigments collected from nearshore sampling near Palmer Station and from annual shipbased cruises along the WAP, as well as high-resolution bathymetry, highresolution satellite-based sea ice coverage, SST, and ocean color data, we tested hypotheses 1 and 3 (above) across multiple canyons along the WAP. Specifically, we addressed the following questions. Are canyons associated with measureable differences in sea ice coverage and SST relative to adjacent shelf areas? Do canyons aggregate enhanced phytoplankton biomass compared with adjacent shelf areas? Do we see variations in the community structure of phytoplankton above canyons? Do these patterns vary seasonally and/or spatially? And finally, to inform climate projections, how are the overlying patterns affected by spatiotemporal variability in seasonal sea ice coverage?

\section{MATERIALS AND METHODS}

\section{In situ data}

In situ data were collected as part of the regular sampling of the Palmer Long-Term Ecological Research (PAL-LTER; http://pal.lternet.edu/). Since 1993, the PAL-LTER has conducted regional oceanographic and biogeochemical sampling each January over a grid of hydrographic stations extending $400 \mathrm{~km}$ north-south along the WAP, and from the nearshore region $(<300 \mathrm{~m}$ depth) to the slope region beyond the shelf break $(>3000 \mathrm{~m})$, about $200 \mathrm{~km}$ from the coast (Fig. 1). Beginning in 2009, the latitudinal grid was extended an additional $300 \mathrm{~km}$ to the south in order to include areas with more extensive sea ice cover. In addition, regular twice-weekly nearshore sampling at Palmer Station from October to April provides a seasonal context for the January shelf-wide observations. Pigment concentrations were measured using reverse phase

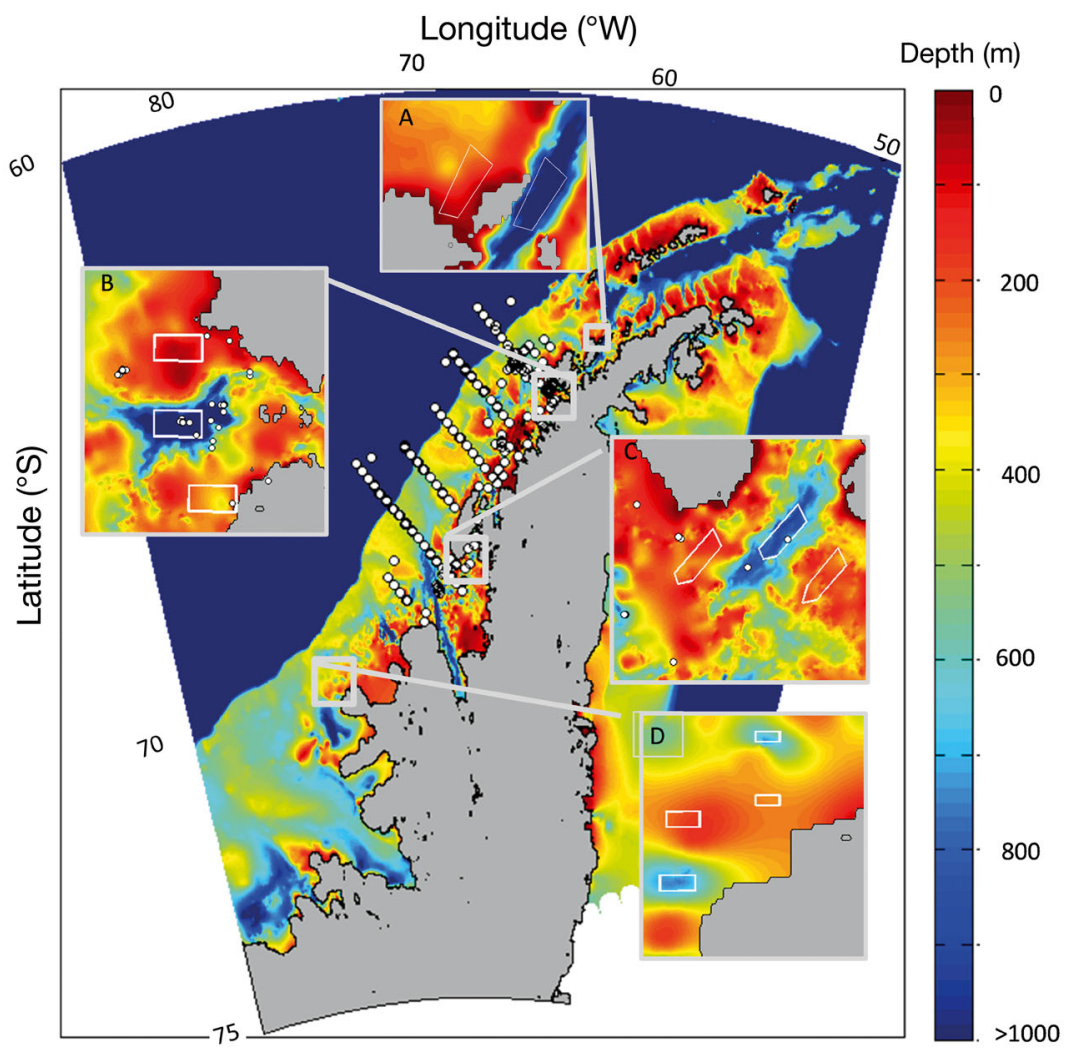

Fig. 1. Bathymetry along the Western Antarctic Peninsula continental shelf. Spatial resolution is $500 \mathrm{~m}$ (source: Bedmap 2). White dots denote location of HPLC samples taken as part of the Palmer LTER annual surveys used to inform the fucoxanthin algorithm from remotely sensed reflectances. Insets show polygon regions of interest and in situ samples where applicable for (A) North Brabant, (B) Palmer Deep, (C) Avian Island and (D) Charcot Island. Coordinates and summary statistics are listed in Table 1 
HPLC (Wright et al. 1991, Kozlowski et al. 2011) and provided proxies for total phytoplankton community biomass ( $\mathrm{chl}$ a), diatom biomass (fucoxanthin), and diatom relative abundance (fucoxanthin: $\mathrm{chl}$ a). We recognize that variations in phytoplankton carbon:chl a ratios exist in many regions of the world ocean due to physiological acclimation to light, nutrients, or temperature (e.g. Geider et al. 1998). However, chl a and phytoplankton carbon are well correlated in the Southern Ocean (Arrigo et al. 2008) and the northern WAP (Mendes et al. 2012). In phytoplankton, fucoxanthin is confined to diatoms, prymnesiophytes (such as Phaeocystis spp.), raphidophytes, and chrysophytes (Wright \& Jeffrey 1987); the latter 2 taxa are not well represented along the WAP. Phaeocystis has 1/10 the fucoxanthin to chl a ratio of diatoms in iron-replete conditions and has undetectable concentrations of fucoxanthin when iron is limited (Aldercamp et al. 2012). Additionally, Phaeocystis does not appear to have a significant presence at Palmer Station.

\section{High-resolution bathymetry}

Four canyons and adjacent shelf 'controls' were defined along the WAP (Fig. 1) using high-resolution bathymetry. Bathymetry was based on seafloor and subglacial bed elevation of the Antarctic (Bedmap2; Fretwell et al. 2013). The product Bedmap2 combines multiple sources primarily from the British Antarctic Survey and has a $500 \mathrm{~m}$ horizontal resolution. Canyons were defined as localized contiguous regions on the continental shelf with depths $>700 \mathrm{~m}$. Once canyon polygons were delineated, adjacent shallow $(<250 \mathrm{~m})$ shelf areas were also defined using the same size polygon with minimal change in pixel count (Table 1). These 4 canyons represent a subset of canyons along the WAP latitudinal gradient, and landward of the canyon heads, penguin colonies are known to exist, either currently or in the recent past (Fraser \& Trivelpiece 1996, Schofield et al. 2013).

\section{Sea ice coverage}

We utilized the GSFC Bootstrap SMMR-SSM/I Version 2 quasi-daily time series (1979-2010) of sea ice concentration (Comiso et al. 1997, Comiso
2010, 2012) from the EOS Distributed Active Archive Center (DAAC) at the National Snow and Ice Data Center (NSIDC, University of Colorado at Boulder, http://nsidc.org). Sea ice concentration is derived from brightness temperatures acquired from the following satellites and sensors: the NASA Nimbus-7 Scanning Multi-channel Microwave Radiometer (SMMR) and the Defense Meteorological Satellite Program (DMSP)-F8, -F11 and F13 Special Sensor Microwave/Imagers (SSM/I), and the DMSP-F17 Special Sensor Microwave Imager/Sounder (SSMIS). Sea ice concentration is the fraction of surface area covered by sea ice and is hereafter referred to as sea ice coverage (in percentage). Sea ice concentrations were maintained on their native grid $(25 \times 25 \mathrm{~km})$ but binned into 8 $\mathrm{d}$ averages. Spring ice retreat dates were identified as the first day sea ice concentration fell below $15 \%$ (e.g. Stammerjohn et al. 2008) using smoothed ( $7 \mathrm{~d}$ running average) daily data.

\section{Satellite ocean color}

MODIS-Aqua Level 2B data were downloaded for the WAP region and binned into daily geometric means. Ocean color and SST files were binned onto the same grid prior to temporal averaging using a nearest neighbor technique to interpolate over the domain of 85 to $50^{\circ} \mathrm{W}$ and 75 to $60^{\circ} \mathrm{S}$. The grid maintained $\sim 1 \mathrm{~km}$ resolution and thus was 1926 pixels wide at $60^{\circ} \mathrm{S}$ and 998 pixels at $75^{\circ} \mathrm{S}$. MODIS Level $2 \mathrm{~b}$ Ocean Color data include 5 remote sensing reflectances $\left(R_{\mathrm{rs}}\right)$ at the following wavelengths: 412,443 ,

Table 1. Summary of bathymetric regions of interest (ROI) used in the study. Latitude (Lat.) and longitude (Long.) are coordinates for the centroid of the ROI. Depth and area are for the ROI, not the entire feature

\begin{tabular}{|llcccc|}
\hline Region & & $\begin{array}{c}\text { Lat. } \\
\left({ }^{\circ} \mathrm{S}\right)\end{array}$ & $\begin{array}{c}\text { Long. } \\
\left({ }^{\circ} \mathrm{W}\right)\end{array}$ & $\begin{array}{c}\text { Mean } \\
\text { depth }(\mathrm{m})\end{array}$ & $\begin{array}{c}\text { Mean area } \\
\left(\mathrm{km}^{2}\right)\end{array}$ \\
\hline North Brabant & - canyon & 64.01 & 61.74 & 1105 & 93.9 \\
& - shelf & 63.98 & 62.09 & 104 & 87.5 \\
Palmer Deep & - N shelf & 64.77 & 64.42 & 115 & 81.4 \\
& - canyon & 64.94 & 64.42 & 1190 & 81.4 \\
& - S shelf & 65.11 & 64.24 & 149 & 77.8 \\
Avian Island & - W shelf & 67.89 & 68.76 & 205 & 84.4 \\
& - canyon & 67.82 & 68.16 & 822 & 86.0 \\
& - E shelf & 67.93 & 67.87 & 229 & 75.5 \\
Charcot Island & - N canyon & 69.56 & 75.70 & 616 & 14.2 \\
& - N shelf & 69.68 & 75.70 & 241 & 14.1 \\
& - W canyon & 69.84 & 76.08 & 698 & 27.2 \\
& - W shelf & 69.72 & 76.05 & 206 & 25.6 \\
\hline
\end{tabular}


488,531 and $555 \mathrm{~nm} . R_{\mathrm{rs}}$ is computed by dividing normalized water leaving radiances (nLw) by the mean solar irradiance (Gordon \& Wang 1994), has units of per steradian $\left(\mathrm{sr}^{-1}\right)$, and is now provided as a standard NASA Level 2 product.

Standard OC-3 and OC-4 MODIS-Aqua algorithms tend to underestimate $\mathrm{chl}$ a concentrations along the WAP (Dierssen \& Smith 2000). Dierssen \& Smith (2000) found that the following algorithm to compute chl a (in $\mathrm{mg} \mathrm{m}^{-3}$ ) works well for the WAP:

$\log _{10}(\mathrm{chl} a)=0.641-2.058 R-0.442 R^{2}-1.140 R^{3}$

where $R=\log _{10}\left(R_{\mathrm{rs} 488} / R_{\mathrm{rs} 555}\right)$ and $R_{\mathrm{r} 5488}$ and $R_{\mathrm{r} 5555}$ are the remote sensing reflectances at 488 and $555 \mathrm{~nm}$, respectively. The algorithm is confirmed with our comparisons to in situ chl a (Fig. 2). A remotesensing estimate of fucoxanthin concentration was determined empirically using multiple linear regression (MLR) on remote sensing reflectances $\left(R_{\mathrm{rs}}\right)$. Mixed step-wise MLR analyses were conducted to determine the combination of wavelengths and wavelength ratios (to $555 \mathrm{~nm}$ ) with interactions that resulted in a best empirical fit (probability to enter and leave of 0.25). The stepwise process was stopped using the Akaike criterion, which penalizes models that are overly complex to reduce the likelihood of over-fitting. Match-ups to in situ data were conducted on the same day, using the geometric mean of the remotesensing data in a $1 \mathrm{~km}$ circle centered on the in situ data point (Fig. 2). The final model explained $89 \%$ of the variance for fucoxanthin $\left(\mathrm{mg} \mathrm{m}^{-3}\right)\left(F_{\text {stat }}=\right.$ $32.4, \mathrm{df}=3,48, \mathrm{p}<0.001, R^{2}=0.89$; Fig. $2 \mathrm{C}$ ) and is represented by the following empirical relationship (Table 2):

$$
\begin{aligned}
\log _{10}(\text { fucoxanthin })= & 1.49-0.67 X_{1}+ \\
& 1.98 X_{2}-2.33 X_{3}
\end{aligned}
$$

where $X_{1}, X_{2}$ and $X_{3}$ are the reflectance ratios at 412,443 , and $488 \mathrm{~nm}$ to $555 \mathrm{~nm}$, respectively. Note that the high reflectance ratio spikes $(>10)$ were removed. In global algorithms (Alvain et al. 2008), these 3 wavelengths differentiate waters with diatom dominance. Pure fucoxanthin would be expected to absorb light strongly at $488 \mathrm{~nm}$ wavelength and weakly at $412 \mathrm{~nm}$ (Wright \& Jeffrey 1987), and diatoms scatter light efficiently at the lower wavelengths (e.g. Vaillancourt et al. 2004). For both chl $a$ and fucoxanthin, only satellitederived values within the range of the in situ pigments were used $\left(0.1-35 \mathrm{mg} \mathrm{m}^{-3}\right.$ for both chl $a$ and fucoxanthin).
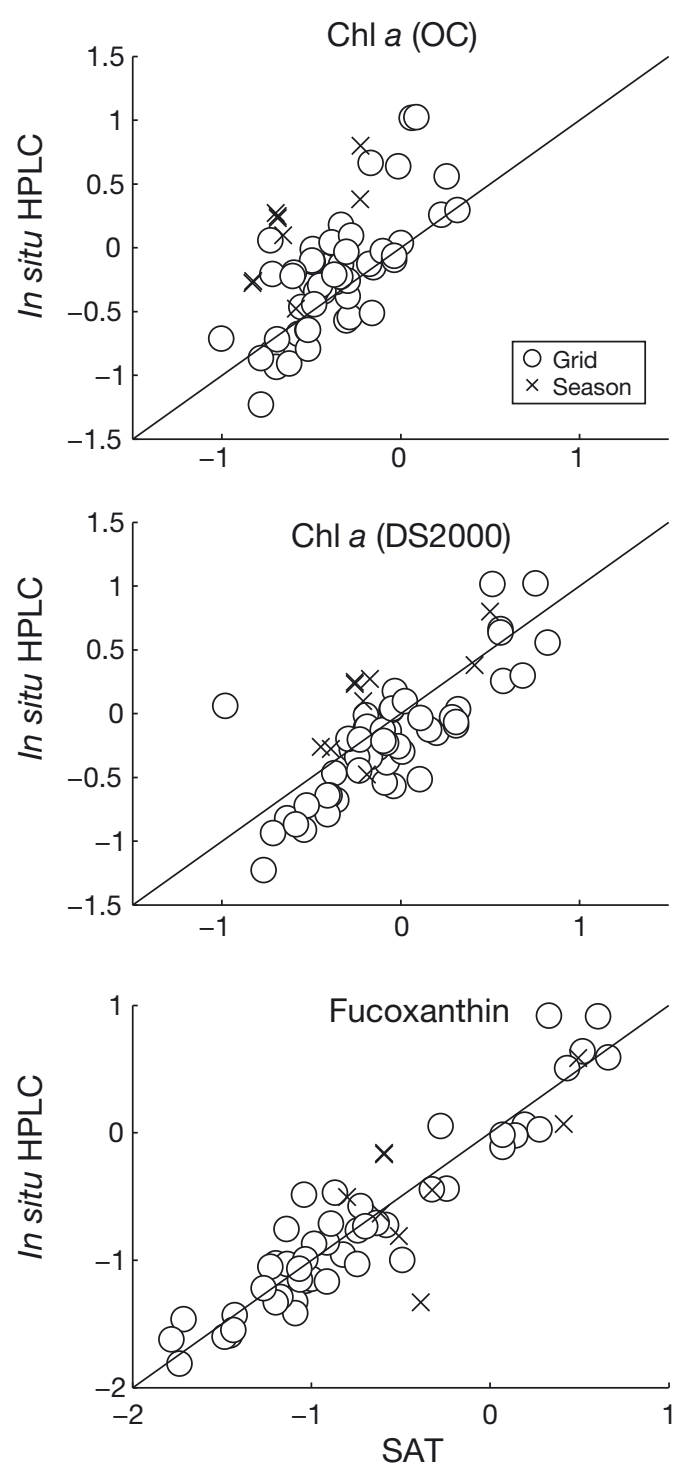

Fig. 2. Relationship of chlorophyll a (chl a) and fucoxanthin predicted from MODIS-Aqua remotely sensed reflectances (SAT) to in situ HPLC pigments. All values are $\log _{10}$-transformed, in units of $\mathrm{mg} \mathrm{m}^{-3}$, and reflect match-ups with $1 \mathrm{~km}$ pixels across the cruise grid (circles) and seasonal sampling near Palmer Station $(\times)$. Line depicts 1:1. OC: standard NASA chl a algorithm; DS2000: Dierssen \& Smith 2000; fucoxanthin: present study

Table 2. Regression statistics for satellite-derived fucoxanthin concentration from remote sensing reflectance ratios ( $R_{\mathrm{rs}}$ relative to $R_{\mathrm{rs}}$ at $550 \mathrm{~nm}$ )

\begin{tabular}{|lrcrc|}
\hline & Mean & $\mathrm{SE}$ & $t$ & $\mathrm{p}$ \\
\hline Intercept & 1.4519 & 0.1217 & 11.9260 & $<0.0001$ \\
$R_{412}$ & -0.6897 & 0.1368 & -5.0434 & $<0.0001$ \\
$R_{447}$ & 1.9821 & 0.2836 & 6.9889 & $<0.0001$ \\
$R_{488}$ & -2.3330 & 0.1859 & -12.5489 & $<0.0001$ \\
\hline
\end{tabular}




\section{Statistics}

Time series were created by averaging (geometric where appropriate) the pixels within the polygons described above. Concurrent ocean color, SST, and sea ice data were available from July 2002 through the end of 2010. For the present study, we considered the geometric mean (Campbell 1995) of pigment concentrations averaged over the first optical depth ( $37 \%$ surface irradiance $=\sim 15 \mathrm{~m})$. Paired $t$-tests were conducted on sea ice, SST, chl $a$, and fucoxanthin across all years to determine whether canyons and shelf areas were significantly different in these properties within and across years. The mean percents (as opposed to the percent of the means) are reported for ice, chl $a$, and fucoxanthin; the mean difference is reported for SST. In situ chl a and fucoxanthin were also compared with satellite estimates across 2 regions of interest, Palmer Deep and Avian Island (Table 1; see Fig. 1 for site locations). Because seasonal sampling at Palmer Deep is restricted to shallow waters and the canyon head and was not available for Avian Island, only cruise data were used and thus restricted to Januarys of 2003-2009 (Palmer Deep, $\mathrm{N}=34$; Avian Island, $\mathrm{N}=20$ ). ANOVA was used to determine whether in situ properties above canyons were significantly different from adjacent shelf areas.

\section{RESULTS}

\section{Pixel retrieval at $8 \mathrm{~d}$ frequency}

Sensitivity to determine differences between canyons and adjacent shelf areas is affected by sufficient cloud-free or otherwise flagged pixels and within-region heterogeneity. For chl $a$, detectable differences were $~ 5 \%$ at North Brabant and Charcot Island, $8 \%$ at Palmer Deep, and $15 \%$ at Marguerite Bay (Fig. A1 in the Appendix). For fucoxanthin, detectable differences were $10 \%$ at all canyons except Marguerite Bay, where spatial heterogeneity likely resulted in lower sensitivity ( $27 \%$ minimum difference). Low signal to noise pixels are flagged in Level 2 data; for MODIS Aqua, on-orbit signal to noise ratio at $412 \mathrm{~nm}$ is adequate to obtain a surface signal after atmospheric correction, but less than that of the chl a wavelengths (1.3 compared with >1.6; Xiong et al. 2002). Because the fucoxanthin algorithm relies on the $R_{\mathrm{rs}}$ $412 \mathrm{~nm}$ band, retrieval of the fucoxanthin was slightly less (1-3\%) than that of chl $a$ in time, but did not vary significantly from that of chl $a$ in space.

\section{Sea ice effects}

Seasonal sea ice coverage exhibited latitudinal variability, with winter maxima in percent sea ice cover in the northern sites averaging $<30 \%$ at North Brabant and $\sim 50 \%$ at Palmer Deep (Fig. 3). Although some years in the recent record saw much greater winter sea ice coverage (2005 and 2006), no years saw complete $(100 \%)$ winter ice coverage at these 2 northern sites. Avian Island, by contrast, had an average winter sea ice coverage of $\sim 80 \%$ (Fig. 3), with some years $(2003,2005-2006)$ reaching over $95 \%$ (Fig. 4). Starting in 2007, all sites exhibited relatively lower sea ice coverage, including the 2 southern sites (Avian and Charcot). Charcot Island often reached complete $(100 \%)$ winter sea ice coverage and was not ice-free during the summers of 2005 and 2006. Sea ice duration also was variable, with the spring sea ice retreat at North Brabant and Palmer Deep often occurring well before 1 January, with the exception of 2005 and 2006. The spring sea ice retreat at Avian Island lagged that at Palmer Deep by $\sim 2 \mathrm{wk}$, with pre-1 January retreats occurring from 2007 onward.

Sea ice coverage varied substantially over the satellite record (Fig. 4) but generally followed patterns outlined by Stammerjohn et al. (2008). Interannual sea ice reductions were evident (e.g. more than 1 standard deviation lower than the 1979-2002 average) as indicated by lower late winter/early spring (Sep-Oct) sea ice coverage and earlier spring sea ice retreat, particularly from 2007 to 2010 (Fig. 4C-F). Late winter/early spring sea ice coverage was often slightly lower over the canyon versus the adjacent shelf area at Palmer Deep (Fig. 4C), while an earlier spring sea ice retreat occurred frequently over the canyon (versus adjacent shelf area) (Fig. 4E). At Avian Island, late winter/early spring sea ice coverage was persistently less over the canyon (versus the adjacent shelf area) (Fig. 4D), but there was little difference in the timing of spring sea ice retreat between those 2 areas (Fig. 4F).

Canyons, on average, had reduced sea ice coverage compared with adjacent shelf areas (Figs. 3-5), except at Charcot. In contrast, sea ice phenology appeared more variable between canyon and adjacent shelf areas. At North Brabant and Palmer Deep, lower winter sea ice coverage in the canyons was also accompanied by earlier spring sea ice retreat. While the spring sea ice retreat in general became earlier over the study period (e.g. Fig. 4), retreat timing was not different between the canyon and adjacent shelf area at Avian Island between 2002 and 2010 (Figs. 3, 5). At any given time period, winter sea 

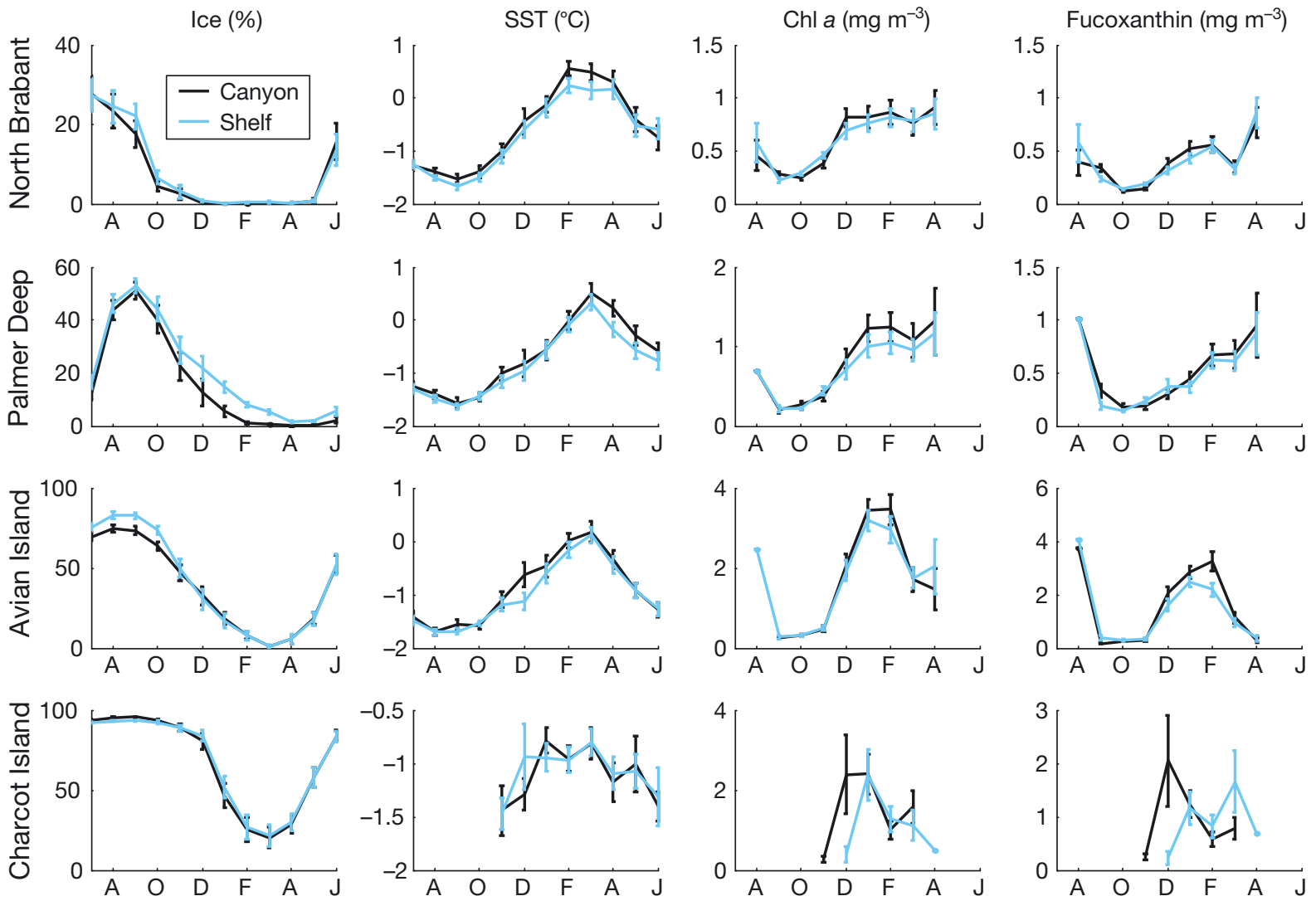

Fig. 3. Seasonal cycle (mean \pm SE) of satellite-based properties derived from monthly climatologies (July 2002-June 2010). Canyons are denoted by black lines; respective shelves are denoted by blue lines
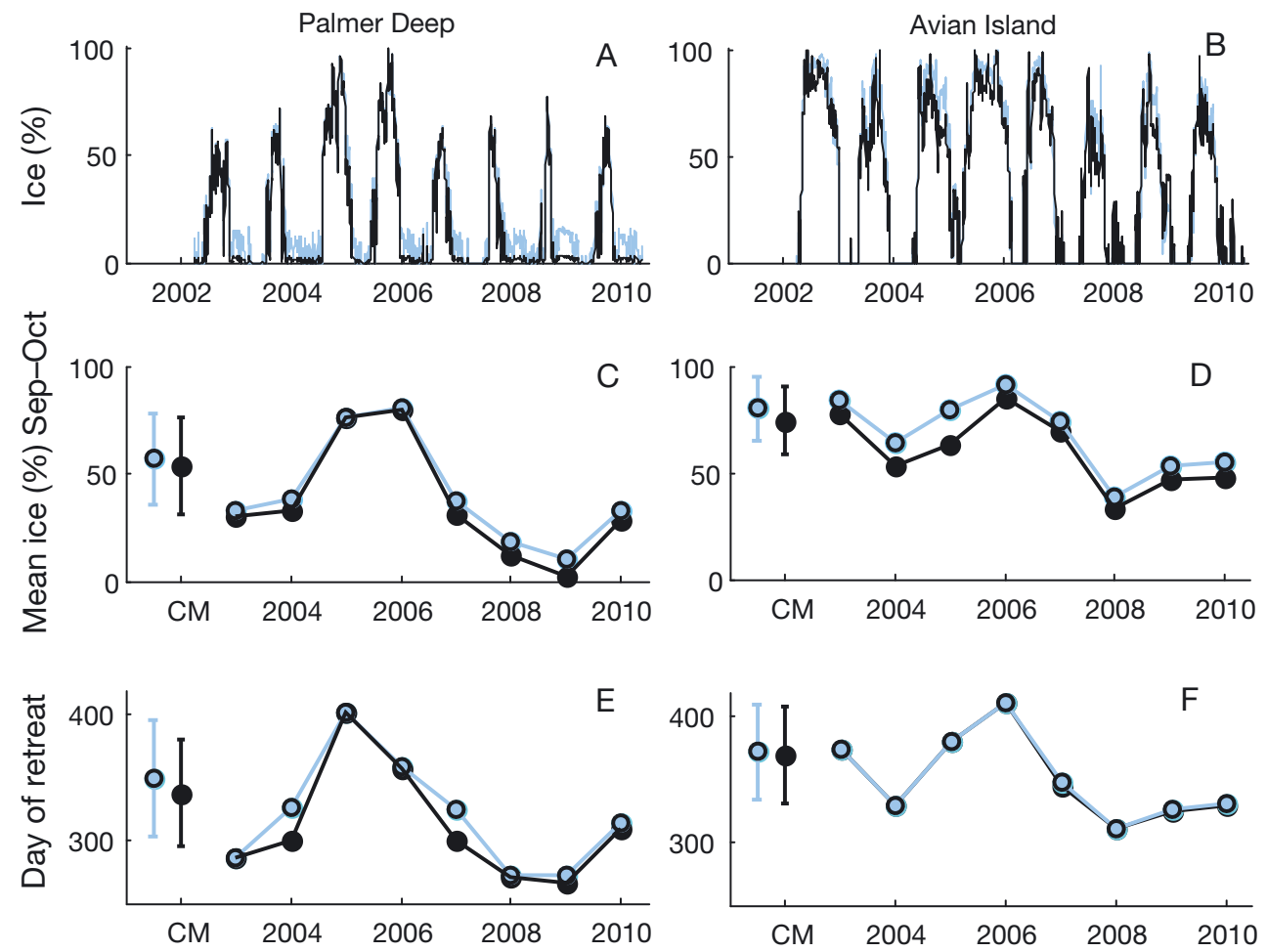

Fig. 4. Local sea ice patterns for Palmer Deep and Avian Island canyons (black) and adjacent shelf areas (blue) preceding annual cruises (January 2003-2010). CM: climatological mean through satellite record (1979-2002). $(A, B)$ Variability in sea ice coverage (\%) over canyons and adjacent shelf areas ( $7 \mathrm{~d}$ running averages). $(C, D)$ Mean preceding winter sea ice percentages calculated from 1 July to 31 October for each year. $(E, F)$ Ice retreat year day calculated as the first day local spring sea ice coverage declined below $15 \%$. Note that in some years, the day of sea ice retreat occurred after 1 January 

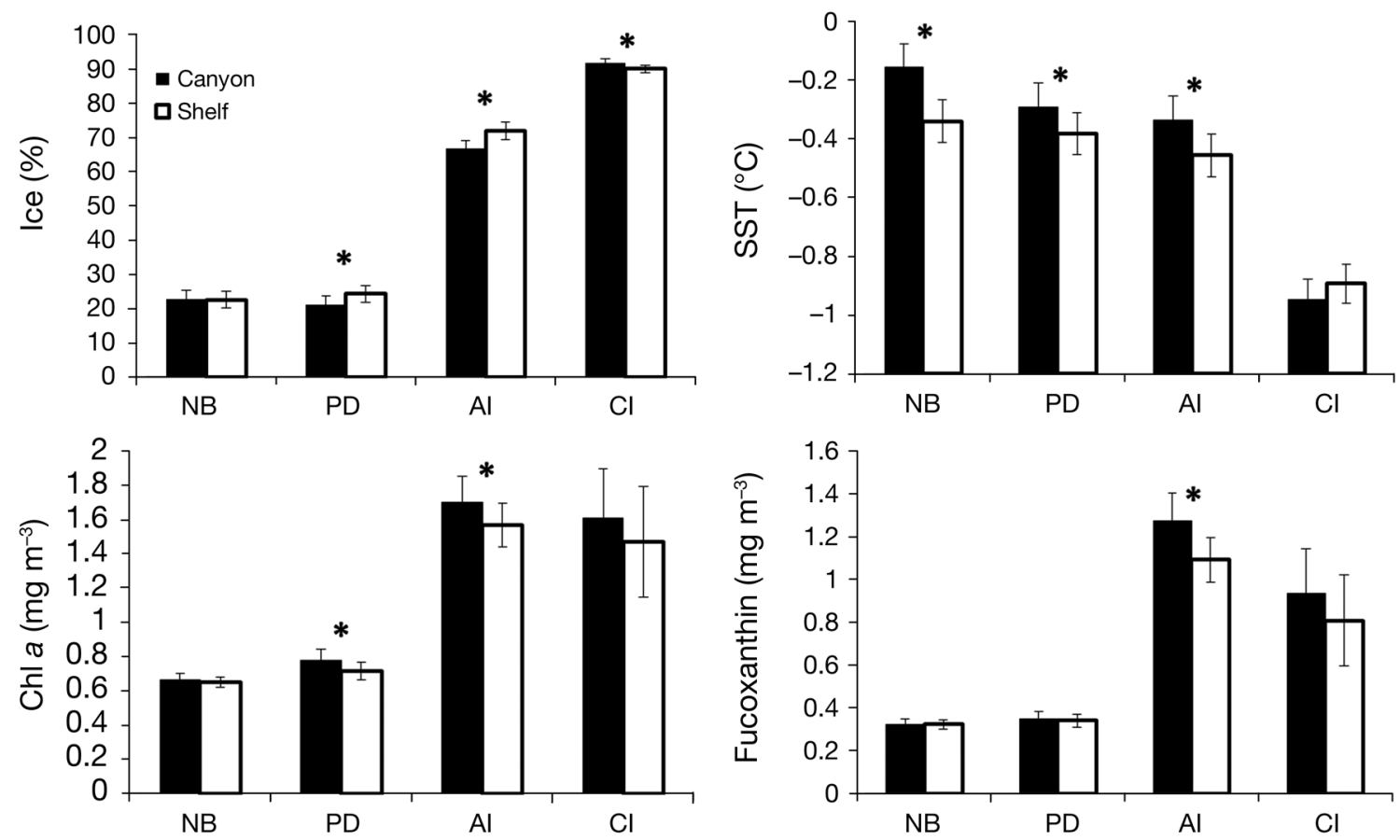

Fig. 5. Mean $( \pm$ SE) sea ice coverage, sea surface temperature (SST), chlorophyll a (chl a) and fucoxanthin (July 2002-June 2010) for 4 canyons and adjacent shelf areas along the western side of the Antarctic Peninsula. NB: North Brabant; PD: Palmer Deep; AI: Avian Island; CI: Charcot Island. Mean values were calculated for matching canyon and shelf pairs, compiling $8 \mathrm{~d}$ averages from June through August for sea ice coverage, and October through April for SST, chl $a$, and fucoxanthin proportion. Asterisks denote significant differences (paired $t$-test, $\mathrm{p}<0.05$ )

ice coverage was on average $10 \%$ lower (Table 3 , Fig. 3) and sometimes as much as $15 \%(2006-2007)$ or $20 \%$ (2002-2003) lower over the canyon. At Charcot Island, both the canyon and the shelf exhibited high sea ice concentrations year-round; however, spring sea ice concentrations were significantly lower over the canyon (Table 3 ).

\section{SST effects}

Spring through fall mean SST exhibited a latitudinal gradient, with a gradual decrease in mean SST with latitude from North Brabant $\left(\sim-0.2^{\circ} \mathrm{C}\right)$ to Palmer Deep $\left(-0.3^{\circ} \mathrm{C}\right)$ to Avian Island $\left(-0.4^{\circ} \mathrm{C}\right)$, and then a large decrease to Charcot Island $\left(-0.9^{\circ} \mathrm{C}\right)$. With the exception of Charcot Island, summertime temperatures averaged above $0^{\circ} \mathrm{C}$, with temperatures nearing $1^{\circ} \mathrm{C}$ in the northern canyons (Fig. 3). However, there were qualitative differences in the timing: warmer canyon temperatures occurred in early spring in Marguerite Bay and in summer in the northern 2 canyons. Canyons, on average, had warmer spring to fall temperatures than the adjacent shelf areas $\left(>+0.1^{\circ} \mathrm{C}_{i}\right.$ Fig. 5 , Table 3$)$.

\section{Phytoplankton dynamics}

Phytoplankton biomass did not exhibit a latitudinal gradient, but rather a maximum at Avian Island, with spring-summer chl a averaging $\sim 1.5 \mathrm{mg} \mathrm{m}^{-3}$ and almost $4 \mathrm{mg} \mathrm{m}^{-3}$ during January and February. Charcot Island exhibited slightly less chl a $\left(\sim 2 \mathrm{mg} \mathrm{m}^{-3}\right.$ January average), with a sharp biomass decline in February. Annual means at Palmer Deep and North Brabant ( $\sim 0.6$ and $\sim 0.7 \mathrm{mg} \mathrm{m}^{-3}$, respectively) were much lower than at Avian Island. Concentrations of chl a were episodically higher over the canyons (Figs. 5, 6; discussed in more detail below); over the time series there was a positive effect of canyons on chl $a$ at Palmer Deep and Avian Island (Figs. 3, 5), but a limited effect at Charcot Island in part to small sample size.

Diatom abundance, as inferred by satellite-derived fucoxanthin, followed a similar latitudinal pattern as chl $a$, with an optimum at Avian Island, where the concentration of fucoxanthin averaged $1.3 \mathrm{mg} \mathrm{m}^{-3}$ but reached $>3 \mathrm{mg} \mathrm{m}^{-3}$ in summer (Fig. 3). Diatom biomass declined to the south and north, where biomass at Charcot Island and Palmer Deep averaged 0.94 and $0.35 \mathrm{mg} \mathrm{m}^{-3}$, respectively. Diatom abun- 
Table 3. Summary statistics of remotely sensed variables over canyons and adjacent shelves. Regions of interest (ROI) are coded as follows: North Brabant (NB), Palmer Deep (PD), Avian Island (AI) and Charcot Island (CI). Means and standard errors (SE) are reported for sea ice, pigments and sea surface temperature (SST). Mean differences are reported as mean percentage change of canyon from shelf values across time period of interest; SST reflects mean absolute differences in ${ }^{\circ} \mathrm{C}$ (see 'Materials and methods'). $t$-values are the result of paired $t$-tests. Bold values denote statistically significant differences

\begin{tabular}{|c|c|c|c|c|c|c|}
\hline ROI & Canyon (SE) & Shelf (SE) & Difference (SE) & Count & $t$ & Prob $(<|t|)$ \\
\hline \multicolumn{7}{|c|}{ Winter ice: Jun-Aug } \\
\hline NB & $22.9(24.1)$ & $22.6(22.9)$ & $6.8(4.3)$ & 88 & 1.16 & 0.251 \\
\hline PD & $21.1(23.7)$ & $24.4(23.0)$ & $-40.7(4.3)$ & 88 & -10.62 & $<0.001$ \\
\hline AI & $66.7(20.6)$ & $71.9(23.6)$ & $-2.7(2.1)$ & 88 & -8.87 & $<0.001$ \\
\hline CI & $91.7(10.6)$ & $90.0(9.7)$ & $1.7(0.2)$ & 88 & 9.71 & $<0.001$ \\
\hline \multicolumn{7}{|c|}{ Spring ice: Sep-Oct } \\
\hline NB & $0.91(3.64)$ & $1.28(4.57)$ & $-39.1(5.7)$ & 24 & -1.75 & 0.09 \\
\hline $\mathrm{PD}$ & $13.6(23.6)$ & $21.6(21.8)$ & $-15.3(3.2)$ & 24 & -13.8 & $<0.001$ \\
\hline AI & $32.8(27.6)$ & $32.4(31.8)$ & $12.8(0.8)$ & 24 & 0.28 & 0.78 \\
\hline $\mathrm{CI}$ & $72.0(31.3)$ & $75.0(28.0)$ & $-1.7(0.3)$ & 24 & -2.49 & $<0.05$ \\
\hline \multicolumn{7}{|c|}{ SST: Oct-Apr } \\
\hline NB & $-0.15(1.07)$ & $-0.34(1.00)$ & $0.18(1.1)$ & 191 & 4.74 & $<0.001$ \\
\hline PD & $-0.29(1.02)$ & $-0.38(0.89)$ & $0.09(1.0)$ & 157 & 2.44 & $<0.01$ \\
\hline AI & $-0.33(1.01)$ & $-0.46(0.91)$ & $0.12(1.2)$ & 152 & 3.29 & $<0.01$ \\
\hline $\mathrm{CI}$ & $-0.95(0.62)$ & $-0.89(0.58)$ & $0.05(2.3)$ & 76 & -0.76 & 0.4518 \\
\hline \multicolumn{7}{|c|}{ Chlorophyll a: Oct-Apr } \\
\hline NB & $0.66(0.04)$ & $0.65(0.03)$ & $8.5(3.0)$ & 131 & 0.67 & 0.5 \\
\hline PD & $0.78(0.06)$ & $0.71(0.05)$ & $21.9(7.0)$ & 100 & 2.06 & $<0.05$ \\
\hline AI & $1.71(0.15)$ & $1.56(0.13)$ & $21.5(7.0)$ & 114 & 2.21 & $<0.05$ \\
\hline $\mathrm{CI}$ & $1.61(0.28)$ & $1.46(0.32)$ & $51.9(34)$ & 16 & 0.52 & 0.61 \\
\hline \multicolumn{7}{|c|}{ Fucoxanthin: Oct-Apr } \\
\hline NB & $0.33(0.03)$ & $0.33(0.02)$ & $11.4(4.6)$ & 131 & 0.2 & 0.84 \\
\hline PD & $0.35(0.04)$ & $0.34(0.03)$ & $13.9(6.0)$ & 100 & 0.09 & 0.93 \\
\hline AI & $1.27(0.13)$ & $1.09(0.10)$ & $35(7.5)$ & 114 & 3.72 & $<0.001$ \\
\hline $\mathrm{CI}$ & $0.94(0.21)$ & $0.81(0.21)$ & $98(61)$ & 16 & 0.65 & 0.52 \\
\hline
\end{tabular}
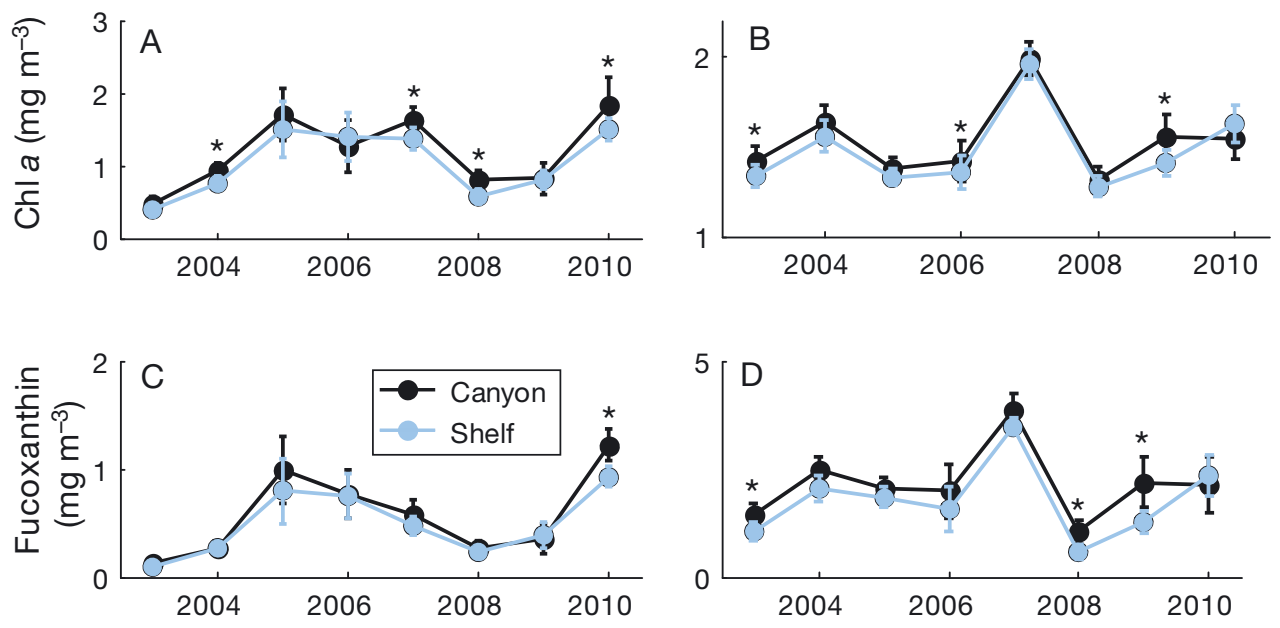

Fig. 6. Mean $( \pm \mathrm{SE})$ chlorophyll a (chl a), fucoxanthin, and fucoxanthin:chl a ratio over the peak growing periods at Palmer Deep (left) and Avian Island (right) for the canyon (black) and the adjacent shelf (blue) areas. Growing period is defined as the temporal average from December to March of
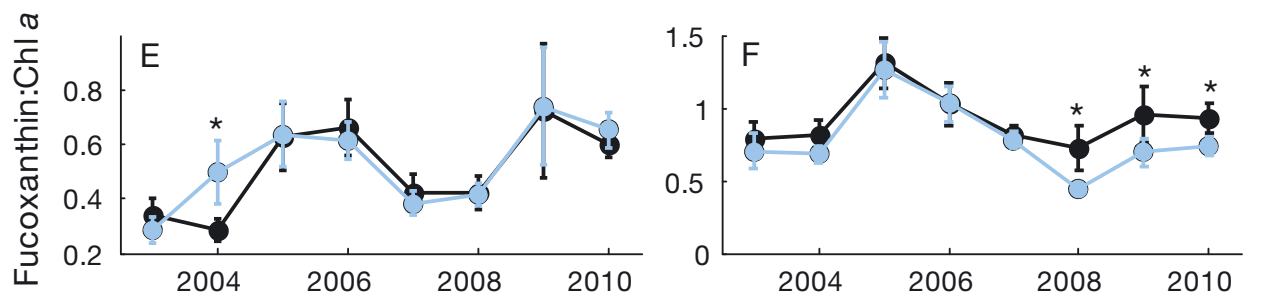
each year. Asterisks denote significant differences $(\mathrm{p}<$ 0.05 , paired $t$-test) between canyons (black line and circles) and adjacent shelf areas (blue line and circles) for the season 
dance was lowest at North Brabant, where fucoxanthin concentrations on the shelf averaged $0.33 \mathrm{mg} \mathrm{m}^{-3}$. The seasonality of diatom relative abundance was somewhat different than that of chl a. Two or more peaks in relative diatom abundance appeared seasonally (Fig. 3), one usually occurring before 1 January and one after.

The effect of canyons on diatom abundances varied latitudinally, with no difference in the northern canyons and higher diatom abundances relative to shelf areas in the southern canyons ( $t$-test, p $<0.05$; Table 3). The effect was greatest at Avian Island (as measured by the change relative to the shelf). The difference was also strong at Charcot Island, although the number of co-occurring measurements was too sparse for statistical significance.

Interannual variation in seasonal sea ice appeared to affect total phytoplankton and diatom specific biomass at both Palmer Deep and Avian Island (Fig. 6), with low pigment concentrations fol-

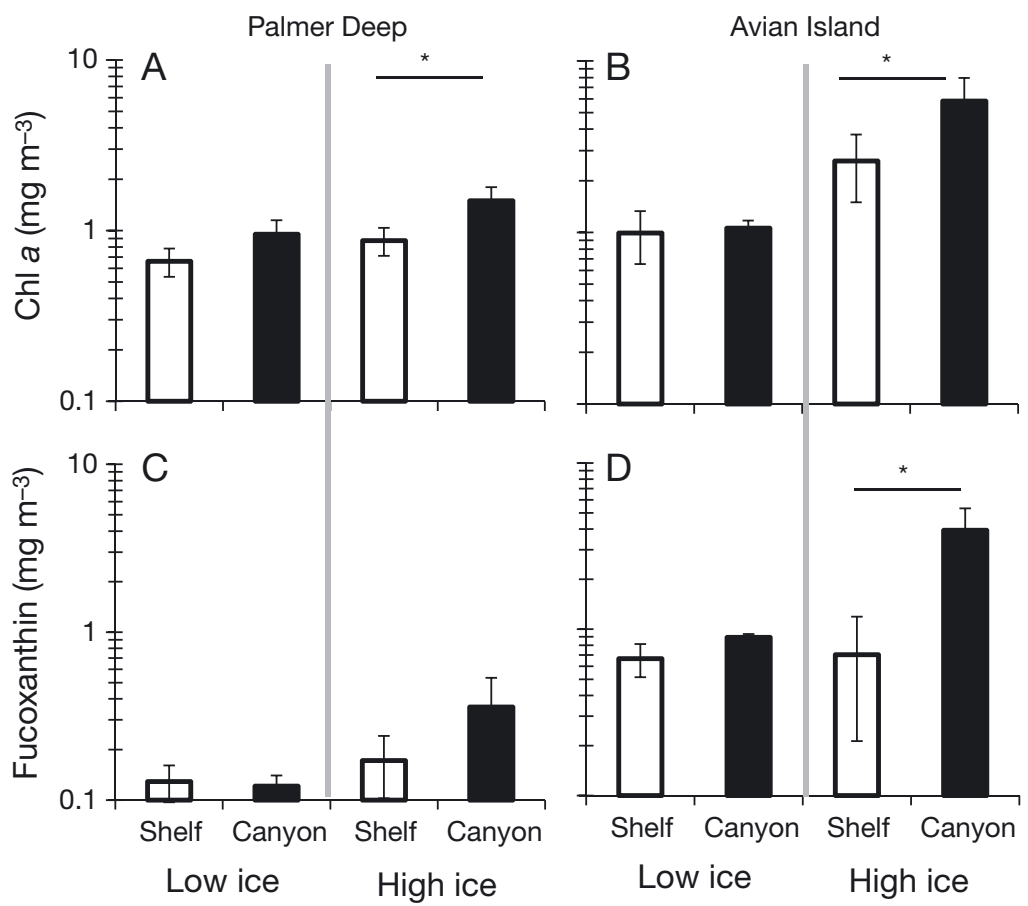

Fig. 7. Mean $( \pm \mathrm{SE})$ pigment patterns comparing canyons and shelves during January cruise from 2003 to 2009. (A) Palmer Deep chlorophyll a (chl a); (B) Avian Island chl $a_{i}$ (C) Palmer Deep fucoxanthin; (D) Avian Island fucoxanthin. Total samples: $\mathrm{N}=34$ at Palmer Deep; $\mathrm{N}=20$ at Avian Island. ${ }^{*} \mathrm{p}<0.05$ (ANOVA) lowing low ice years (2003, 2004, 2008, and 2009 at Palmer Deep, and 2008 and 2009 at Avian Island). At Palmer Deep, increases in chl a were not met with increases in fucoxanthin, resulting in lower relative abundance of diatoms (fucoxanthin:chl a) compared with Avian Island and above the canyon during 2004 and 2010. At Avian Island, potential effects of sea ice variability were minimal; fucoxanthin abundances and relative abundances were persistently high and higher than that at Palmer Deep. The greater diatom relative abundance over canyons was apparent during low sea ice years (Fig. 6F), suggesting that conditions were conducive for diatom dominance to persist at Avian Island, despite reduced total phytoplankton and diatom biomass.

In situ patterns of pigments generally followed that of satellite patterns (Fig. 7), although statistical power was limited due to sparse data availability. During the January cruises, chl a and fucoxanthin concentrations were higher in the Avian Island region than in the Palmer Deep region. In both regions, chl a was higher above the canyon than in adjacent shelf areas in high-ice years following the general pattern revealed by satellite-derived pigments (Fig. 7B,D). Similar to satellite patterns, during low sea ice years at Palmer Deep, the difference

in fucoxanthin between canyon and shelf areas was absent (Fig. 7C), even tending toward reversal, indicating a shift away from local diatom dominance.

\section{DISCUSSION}

Changes in WAP climate and marine ecosystems are dramatic and coherent over several time and spatial scales. As warmer, lower sea ice conditions expand poleward, we may expect short-term increases in phytoplankton abundances because of increased light availability due to less sea ice, followed by decreases in abundances as the summertime water column becomes increasingly less stable. Canyons have episodically higher phytoplankton biomass, as inferred from [chl a], but persistently higher diatom relative abundances than adjacent shelf areas. Canyons have elevated SST during the growing season and exhibit earlier sea ice retreat or decreased winter sea ice, perhaps due to local influences of UCDW. Intrusions of UCDW have been hypothesized to result in enhanced diatom production over the shelves (Prézelin et al. 2000, 2004) and in the Ross Sea (Liu \& Smith 2012). With the excep- 
tion of North Brabant, local increases of phytoplankton biomass ( $\mathrm{chl} \mathrm{a}$ ) are evident at canyons, increases in absolute diatom biomass are evident above the southern canyons, and increased diatom relative abundance is apparent at Avian Island. These patterns are robust despite the strong spatial gradients in chl $a$, with differences in decadal-scale responses of phytoplankton in the northern peninsula compared with the southern peninsula (Montes Hugo et al. 2009) and cross-shelf variability associated with migration of the marginal ice zone (Smith et al. 2008). However, the spatial and temporal patterns observed suggest that the conditions favorable to higher trophic levels at canyons (e.g. increased biomass and proportion of diatoms) may be dampened under low sea ice conditions. Specifically, while canyons maintain high relative diatom proportions during low sea ice conditions at Avian Island, low sea ice conditions at Palmer Deep are associated with total phytoplankton biomass declines, decreases in diatoms, and decreases in the relative proportion of diatoms.

Although limited in number, ocean time series are essential for understanding how ecosystems are responding to long-term changes, including those driven by the climate system (e.g. Ducklow et al. 2009, Karl 2010, Doney et al. 2012). With the maturation of the satellite record, ocean color proxies can extend the inference of these important time series in space and time, despite seasonal sea ice cover and episodic data lapses associated with clouds. However, the use of ocean color proxies in this region is not without caveats (Dierssen 2010). For example, Dierssen \& Smith (2000) found that [chl a] was underestimated along coastal Antarctica with the commonly used OC-2 algorithm, a pattern confirmed here with the more recent MODIS-Aqua record. Moderately low bacterial abundances (e.g. Ducklow et al. 2001, 2012) have been hypothesized to result in less scattering in the blue wavelengths than typical ocean waters (Dierssen \& Smith 2000, Montes-Hugo et al. 2007). The fucoxanthin algorithm we employed also relies on the blue wavelengths, thus it is possible that shifts in bacterial abundances and/or increased glacial melt will result in spatial and temporal biases of the algorithm. On-orbit performance of the $412 \mathrm{~nm}$ band declined from 2002 to 2008 (Xiong et al. 2010), but remained above that which is necessary for atmospheric correction. Importantly, we do not see evidence of annual decline in pixel retrieval at the $8 \mathrm{~d}$ time scale for our fucoxanthin algorithm, with retrieval of fucoxanthin persisting at approximately $80 \%$ of chl a from 2003 to 2012. We also observed similar patterns in the in situ data, suggesting that the spatiotemporal patterns are robust for both satellite-derived chl $a$ and fucoxanthin over the temporal and spatial scales analyzed here.

Canyon dynamics provide a local test bed for investigating how regional and global change might affect bottom-up forcing through phytoplankton abundances, specifically diatoms. With high levels of unused macronutrients year-round, phytoplankton growth and productivity along coastal Antarctica is likely to be co-limited by temperature, iron, and light (Arrigo et al. 1997, Ducklow et al. 2012). In addition, grazing may have an impact on biomass over relatively short spatial and temporal scales (Marrari et al. 2008, Bernard et al. 2012). However, photophysiology, nutrient uptake rates, and grazing preferences are all taxon-specific, which can affect the community composition of phytoplankton, particularly in highly variable environments such as the Southern Ocean (e.g. Petrou \& Ralph 2011). Furthermore, iron limitation, light limitation, and temperature stress may disproportionately affect diatoms (e.g. Lizotte 2001, Alderkamp et al. 2012, Martin et al. 2012). Several factors related to optimal diatom growth conditions likely interact in a non-linear fashion because of the interaction of surface conditions and sea ice with UCDW within canyons.

\section{Sea ice and surface temperature patterns}

Canyons act to reduce the concentration of sea ice early in the growing season (over winter) at the more northern (southern) sites. At Palmer Deep, the spring retreat occurs 8-17 d earlier (1979-2008) over the canyon than the adjacent shelf areas. In regions or periods with sufficient and persistent winter sea ice, the subsequent opening of the pack ice in spring above canyons results in an enhanced and sustained summer phytoplankton bloom relative to adjacent shelf areas and earlier access to foraging by sea birds. However, in regions with minimal winter sea ice (e.g. in the northern regions analyzed here), reduced winter sea ice may result in open water during periods of insufficient insolation, resulting in little benefit for phytoplankton growth rates. Successional shifts from diatoms to cryptophytes may occur earlier as surface salinities drop in response to springsummer glacial melt (Moline et al. 2004). For example, when glacial melt near Palmer Station (on Anvers Island) occurred earlier, shifts towards cryptophyte dominance occurred earlier and were stronger. These early glacial melt years also coincided with earlier sea ice retreat. 
At local scales, canyons are significantly warmer than adjacent shallow shelf areas (present study, $>+0.1^{\circ} \mathrm{C}$ ) across the growing season. The temperature difference likely reflects a combination of enhanced solar warming under more ice-free conditions and the upwelling or mixing of warm UCDW into colder surface waters. The temperature increase is more apparent in mid to late summer in the northern canyons (North Brabant and Palmer Deep) and occurs in spring to early summer off Avian Island. As winter sea ice declines, there is decreased formation of cold winter water that acts as a mixing barrier in the growth season between warm, subsurface UCDW and the surface layer (Martinson et al. 2008, Martinson \& McKee 2012); under lower sea ice conditions, winter and spring intrusions of UCDW may increase, resulting in increased subsurface temperatures and changes in the physiology of overwintering phytoplankton. Thus warmer water upwelled in summer may directly facilitate diatom-specific growth through temperature-related metabolic increases or through the delivery of associated micronutrients. However, the seasonal timing of increased fucoxanthin abundance over canyons occurs independently of a detected temperature effect. Thus temperature variability alone is not sufficient to explain the timing of seasonal increases in diatom abundances that occur both early and late in the season, suggesting that the interaction of UCDW with canyons may ultimately alleviate iron or light limitation for diatom populations.

\section{Biophysical dynamics}

Biophysical dynamics within canyons along the WAP are conducive to phytoplankton production, and, in the southern canyons, higher diatom biomass, although the exact mechanism is still under investigation. The increased SST above canyons suggests that UCDW regularly reaches the surface layer across canyons, which may alleviate light limitation (through mixed layer shoaling) or micronutrient limitation. Water transported through canyons and upwelled or mixed subsequently to the surface may also have elevated bioavailable iron levels due to sedimentary sources. Benthic efflux of coastal sediments is potentially a large source of iron along Antarctic (Marsay et al. 2014) and other coastal margins (e.g. Lam \& Bishop 2008). However, we restricted our remote sensing study to canyon flanks, minimizing effects at canyon heads, where this effect may be the largest. Future efforts could focus on spe- cific ocean color derived products (e.g. Behrenfeld et al. 2009, McGaraghan \& Kudela 2012) and can be coupled with in situ trace metal chemistry and ongoing incubation experiments to determine nutrient sources (e.g. UCDW, glacial melt, resuspended sediments) and phytoplankton responses.

Canyons across the WAP appear to affect phytoplankton community structure on seasonal and interannual scales. Two seasonal shifts in community structure towards diatom dominance are evident in our time series, and both are likely affected by the interaction of canyons and sea ice. The first shift cooccurs with the canonical ice edge melt bloom that occurs early in the season as a function of sea ice melt, freshwater input, and subsequent stratification. A second increase in diatom relative abundance occurs later in the season. At regional scales, these second blooms can be associated with stratification via glacial melt (Dierssen et al. 2002, Ducklow et al. 2007).

Depending on the magnitude of winter sea ice loss and early recession in spring, ice edge blooms may be enhanced (e.g. Charcot) or diminished (e.g. Palmer) over canyons. Blooms under and along the melting edge of sea ice are dominated by diatoms (Lizotte 2001, Martin et al. 2012). The contributions of sea ice algae and overwintering free phytoplankton to 'seeding' the marginal ice edge bloom depends on ecological succession within the sea ice (Lizotte 2001) and overwintering survival strategies such as facultative heterotrophy, resting stages, and reduced metabolism with winter temperatures (Smayda \& Mitchell-Innes 1974, Popels \& Hutchins 2002). In a laboratory study mimicking winter dark conditions, increased temperatures resulted in reduced storage compounds, chl a and physiological state in free-living populations (Martin et al. 2012). Increased temperature also resulted in reduced physiological recovery in both sea-ice-residing and free-living phytoplankton when the lights were increased to mimic spring conditions (Martin et al. 2012). Thus, depending on the magnitude of sea ice loss, decreased winter sea ice cover and earlier phenology may reduce the fitness of overwintering diatoms and change the structure of phytoplankton populations associated with the sea ice edge retreat.

\section{Phytoplankton structure and biomass}

Diatoms increase in abundance again in late summer, with timing associated with the increased SST signature from upwelled UCDW and solar heating. 
While micronutrient availability likely increases with intrusions of UCDW, large extents of open water may be prone to increased mixing and a more variable light environment, particularly in the northern WAP (Montes-Hugo et al. 2009). While total phytoplankton biomass increases above canyons in the northern WAP under these conditions, we see little differences in fucoxanthin. Thus the species assemblage may or may not be conducive to krill production.

Across sites, we observe a regional maximum of total phytoplankton biomass, diatom biomass, and diatom relative abundance at Avian Island within Marguerite Bay. On decadal scales, Montes-Hugo et al. (2009) observed higher chl $a$ in the southern WAP, which includes Marguerite Bay, associated with decreases in sea ice concentration. However, the mean sea ice concentration has declined on regional (Stammerjohn et al. 2008, 2012, Montes-Hugo et al. 2009) and local scales (this study). While moderate sea ice years are associated with high biomass at Avian Island, low sea ice years (e.g. 2008, 2009) are associated with low biomass at both Palmer Deep and Avian Island. Thus we do not observe higher chl a during low sea ice years during our study period at Avian Island, likely because the baseline has shifted toward lower sea ice concentrations. The positive canyon effects on biomass and diatom proportions are diminished or absent in the northern sites, particularly during low sea ice years. We recognize that the in situ data for verification are sparse; however, the patterns are similar for in situ and satellite-based pigments. While phytoplankton may initially respond favorably to the reduced sea ice, interannual declines in sea ice may dampen this effect. As the diatom relative abundance over the canyons shifts towards smaller phytoplankton, we may see decreased export and trophic transfer efficiency of particulate organic carbon as has been inferred from regional studies (e.g. Moline et al. 2004, Sailley et al. 2013).

\section{CONCLUSIONS}

Because of the strong connection with the ACC, canyon studies along the WAP may illuminate the interaction between global and regional climate change. Sediment cores from the Palmer Deep have marked variability in the silt to clay ratio and in micro-fossil composition (Leventer et al. 1996). These changes in productivity and phytoplankton species composition are linked to the extent of glaciation and long-scale variability in the dynamics of the ACC and the flux of warm water of the UCDW onto the conti- nental shelf (Shevenell \& Kennett 2002, Warner \& Domack 2002). How these global and regional climate forcings affect extant ecological interactions is a subject of great interest. Antarctic marine species have a reduced capacity to tolerate increased environmental temperatures, possibly because they have evolved over 14-40 million years to survive stable, sub-zero conditions (Pörtner et al. 2007, Clarke \& Crame 2010). By extension, ice-obligate species such as krill and Adélie penguins may likewise be vulnerable to changes in the amplitude of environmental variability. Since the 1970 s, Adélie penguin breeding pairs near Palmer Station, Anvers Island, have declined by $80 \%$ (Ducklow et al. 2013, Fraser et al. 2013). Our results suggest that habitat loss and physiological stress may be compounded by reduction in food availability through both decreases in total phytoplankton biomass and shifts away from diatom dominance.

Informed from LTER observations, the habitat optimum hypothesis (Fraser \& Trivelpiece 1996) suggests that during the recent high-ice ecological past, canyons may have served to provide a more constant food source for penguins, opening the sea ice earlier (but not too early) for spring foraging and providing bursts of enhanced food supply during the summer. Our results support this hypothesis, linking phytoplankton abundances directly to canyons, which may represent increased food availability for aggregations of krill (Bernard \& Steinberg 2013), with subsequent bottom-up effects on Adélie penguins. However, they also illuminate the interaction of the canyon effect with seasonal sea ice concentrations. Low sea ice in space and time is associated with a reduction in the relative abundance of diatoms and reduced enhancement over the canyons. Thus the transfer to higher trophic levels and particulate organic carbon sinking fluxes over canyons may diminish as the interannual trends in reduced sea ice concentrations continue.

Acknowledgements. We acknowledge support from the National Aeronautics and Space Administration Ocean Biology and Biogeochemistry Program (NNX14AL86G) and the National Science Foundation Polar Programs awards 0823101 (Antarctic Organisms and Ecosystems Program) and 1440435 (Antarctic Integrated System Science) to the Palmer LTER program.

\section{LITERATURE CITED}

Alderkamp AC, Kulk G, Buma AGJ, Visser RJW, Van Dijken GL, Mills MM, Arrigo KR (2012) The effect of iron limitation on the photophysiology of Phaeocystis antarctica 
(Prymnesiophyceae) and Fragilariopsis cylindrus (Bacillariophyceae) under dynamic irradiance. J Phycol 48: 45-59

Allen SE, Vindeirinho C, Thomson RE, Foreman MGG, Mackas DL (2001) Physical and biological processes over a submarine canyon during an upwelling event. Can J Fish Aquat Sci 58:671-684

> Alvain S, Moulin C, Dandonneau Y, Loisel H (2008) Seasonal distribution and succession of dominant phytoplankton groups in the global ocean: a satellite view. Global Biogeochem Cycles 22:GB3001, doi:10.1029/ 2007GB003154

> Arrigo KR, Worthen DL, Lizotte MP, Dixon P, Dieckmann G (1997) Primary production in Antarctic sea ice. Science 276:394-397

Arrigo KR, van Dijken GL, Bushinsky S (2008) Primary production in the Southern Ocean, 1997-2006. J Geophys Res 113, C08004, doi:10.1029/2007JC004551

> Behrenfeld MJ, Westberry TK, Boss ES, O'Malley RT and others (2009) Satellite-detected fluorescence reveals global physiology of ocean phytoplankton. Biogeosciences 6:779-794

> Bernard KS, Steinberg DK (2013) Krill biomass and aggregation structure in relation to tidal cycle in a penguin foraging region off the Western Antarctic Peninsula. ICES J Mar Sci 70:834-849

> Bernard KS, Steinberg DK, Schofield OME (2012) Summertime grazing impact of the dominant macrozooplankton off the Western Antarctic Peninsula. Deep-Sea Res I 62: 111-122

Campbell JW (1995) The lognormal distribution as a model for bio-optical variability in the sea. J Geophys Res Oceans 100(C7):13237-13254

Cimino MA, Fraser WR, Irwin AJ, Oliver MJ (2013) Satellite data identify decadal trends in the quality of Pygoscelis penguin chick-rearing habitat. Glob Change Biol 19: 136-148

> Clarke A, Crame JA (2010) Evolutionary dynamics at high latitudes: speciation and extinction in polar marine faunas. Philos Trans R Soc Lond B Biol Sci 365:3655-3666

Clarke A, Barnes DKA, Bracegirdle TJ, Ducklow HW and others (2012) The impact of regional climate change on the marine ecosystem of the western Antarctic Peninsula. In: Rogers AD, Johnston NM, Murphy EJ, Clarke A (eds) Antarctic ecosystems: an extreme environment in a changing world. Wiley-Blackwell, Oxford, p 91-120

Comiso JC (2010) Polar oceans from space. Springer, New York, NY

Comiso JC (2012) Large decadal decline of the Arctic multiyear ice cover. J Clim 25:1176-1193

> Comiso JC, Cavalieri D, Parkinson C, Gloersen P (1997) Passive microwave algorithms for sea ice concentrations: a comparison of two techniques. Remote Sens Environ 60: 357-384

> Cunha MR, Paterson GL, Amaro T, Blackbird S and others (2011) Biodiversity of macrofaunal assemblages from three Portuguese submarine canyons (NE Atlantic). Deep-Sea Res II 58:2433-2447

Dierssen HM (2010) Perspectives on empirical approaches for ocean color remote sensing of chlorophyll in a changing climate. Proc Natl Acad Sci USA 107:17073-17078

Dierssen HM, Smith RC (2000) Bio-optical properties and remote sensing ocean color algorithms for Antarctic Peninsula waters. J Geophys Res Oceans 105(C11): 26301-26312
Dierssen HM, Smith RC, Vernet M (2002) Glacial meltwater dynamics in coastal waters west of the Antarctic Peninsula. Proc Natl Acad Sci USA 99:1790-1795

Dinniman MS, Klinck JM, Smith WO (2011) A model study of Circumpolar Deep Water on the West Antarctic Peninsula and Ross Sea continental shelves. Deep-Sea Res II 58:1508-1523

> Doney SC, Ruckelshaus M, Emmett Duffy J, Barry JP and others (2012) Climate change impacts on marine ecosystems. Annu Rev Mar Sci 4:11-37

Ducklow H, Carlson C, Church M, Kirchman D, Smith D, Steward G (2001) The seasonal development of the bacterioplankton bloom in the Ross Sea, Antarctica. 19941997. Deep-Sea Res II 48:4199-4221

> Ducklow HW, Baker K, Martinson DG, Quetin LB and others (2007) Marine pelagic ecosystems: the West Antarctic Peninsula. Philos Trans R Soc Lond B Biol Sci 362:67-94

Ducklow HW, Erickson M, Kelly J, Montes-Hugo M and others (2008) Particle export from the upper ocean over the continental shelf of the west Antarctic Peninsula: a longterm record, 1992-2007. Deep-Sea Res II 55:2118-2131

> Ducklow HW, Doney SC, Steinberg DK (2009) Contributions of long-term research and time-series observations to marine ecology and biogeochemistry. Annu Rev Mar Sci 1:279-302

> Ducklow H, Schofield O, Vernet M, Stammerjohn S, Erickson M (2012) Multiscale control of bacterial production by phytoplankton dynamics and sea ice along the western Antarctic Peninsula: a regional and decadal investigation. J Mar Syst 98-99:26-39

Ducklow HW, Fraser WR, Meredith MP, Stammerjohn SE and others (2013) West Antarctic Peninsula: an icedependent coastal marine ecosystem in transition. Oceanography 26:190-203

Fanelli E, Papiol V, Cartes JE, Rumolo P, Brunet C, Sprovieri $M$ (2011) Food web structure of the epibenthic and infaunal invertebrates on the Catalan slope (NW Mediterranean): evidence from $\delta^{13} \mathrm{C}$ and $\delta^{15} \mathrm{~N}$ analysis. Deep-Sea Res I 58:98-109

Fraser WR, Trivelpiece WZ (1996) Factors controlling the distribution of seabirds: winter-summer heterogeneity in the distribution of Adélie penguin populations. In: Ross RM, Hofmann EE, Quetin LB (eds) Foundations for ecological research west of the Antarctic Peninsula. American Geophysical Union, Washington, DC, p 257-272

Fraser W, Patterson-Fraser D, Ribic CA, Schofield O, Ducklow H (2013) A nonmarine source of variability in Adélie penguin demography. Oceanography 26:207-209

Fretwell P, Pritchard HD, Vaughan DG, Bamber JL and others (2013) Bedmap2: improved ice bed, surface and thickness datasets for Antarctica. Cryosphere 7:375-393

Geider RJ, Maclntyre HL, Kana TM (1998) A dynamic regulatory model of phytoplanktonic acclimation to light, nutrients, and temperature. Limnol Oceanogr 43: 679-694

Gordon HR, Wang M (1994) Retrieval of water-leaving radiance and aerosol optical thickness over the oceans with SeaWiFS: a preliminary algorithm. Appl Opt 33:443-452

Hofmann EE, Klinck JM, Lascara CM, Smith DA (1996) Water mass distribution and circulation west of the Antarctic Peninsula and including Bransfield Strait. In:Ross RM, Hofmann EE, Quetin LB (eds) Foundations for ecological research west of the Antarctic Peninsula. American Geophysical Union, Washington, DC, p 61-80 
Huntley ME, Lopez MDG, Karl DM (1991) Top predators in the Southern Ocean: a major leak in the biological carbon pump. Science 253:64-66

Karl DM (2010) Oceanic ecosystem time-series programs. Oceanography 23:104-125

Kozlowski WA, Deutschman D, Garibotti I, Trees C, Vernet M (2011) An evaluation of the application of CHEMTAX to Antarctic coastal pigment data. Deep-Sea Res I 58: 350-364

> Lam PJ, Bishop JKB (2008) The continental margin is a key source of iron to the HNLC North Pacific Ocean. Geophys Res Lett 35:L07608, doi:10.1029/2008GL033294

- Leventer A (1996) Productivity cycles of 200-300 years in the Antarctic Peninsula area: understanding linkages among the sun, atmosphere oceans sea ice and biota. Geol Soc Am Bull 108:1626-1644

> Liu X, Smith WO (2012) Physiochemical controls on phytoplankton distributions in the Ross Sea, Antarctica. J Mar Syst 94:135-144

> Lizotte MP (2001) The contributions of sea ice algae to Antarctic marine primary production. Am Zool 41:57-73

> Marrari M, Daly KL, Hu C (2008) Spatial and temporal variability of SeaWiFS chlorophyll a distributions west of the Antarctic Peninsula: implications for krill production. Deep-Sea Res II 55:377-392

> Marsay CM, Sedwick PN, Dinniman MS, Barrett PM, Mack SL, McGillicuddy DJ Jr (2014) Estimating the benthic efflux of dissolved iron on the Ross Sea continental shelf. Geophys Res Lett 41:7576-7583

Martin A, McMinn A, Heath M, Hegseth EN, Ryan KG (2012) The physiological response to increased temperature in over-wintering sea ice algae and phytoplankton in McMurdo Sound, Antarctica and Tromsø Sound, Norway. J Exp Mar Biol Ecol 428:57-66

> Martinson DG (2012) Antarctic circumpolar current's role in the Antarctic ice system: an overview. Palaeogeogr Palaeoclimatol Palaeoecol 335-336:71-74

> Martinson DG, McKee DC (2012) Transport of warm Upper Circumpolar Deep Water onto the western Antarctic Peninsula continental shelf. Ocean Sci 8:433-442

- Martinson DG, Stammerjohn SE, Iannuzzi RA, Smith RC, Vernet M (2008) Western Antarctic Peninsula physical oceanography and spatio-temporal variability. Deep-Sea Res II 55:1964-1987

McGaraghan AR, Kudela RM (2012) Estimating labile particulate iron concentrations in coastal waters from remote sensing data. J Geophys Res 117, C02004, doi: 10.1029/2011JC006977

Mendes CRB, De Souza MS, Garcia VMT, Leal MC, Brotas V, Garcia CAE (2012) Dynamics of phytoplankton communities during late summer around the tip of the Antarctic Peninsula. Deep-Sea Res I 65:1-14

Meredith MP, King JC (2005) Rapid climate change in the ocean west of the Antarctic Peninsula during the second half of the 20th century. Geophys Res Lett 32, L19604, doi:10.1029/2005GL024042

Mitchell BG, Holm-Hansen O (1991) Observations of modeling of the Antarctic phytoplankton crop in relation to mixing depth. Deep-Sea Res A 38:981-1007

Moline MA, Claustre H, Frazer TK, Schofield O, Vernet M (2004) Alteration of the food web along the Antarctic Peninsula in response to a regional warming trend. Glob Change Biol 10:1973-1980

Montes-Hugo M, Vernet M, Smith R, Carder K (2007) Phytoplankton size-structure on the Western shelf of the
Antarctic Peninsula: a remote sensing approach. Int J Remote Sens 29:801-829

> Montes-Hugo M, Doney SC, Ducklow HW, Fraser W, Martinson D, Stammerjohn SE, Schofield O (2009) Recent changes in phytoplankton communities associated with rapid regional climate change along the western Antarctic Peninsula. Science 323:1470-1473

> Nitsche FO, Jacobs SS, Larter RD, Gohl K (2007) Bathymetry of the Amundsen Sea continental shelf: implications for geology, oceanography, and glaciology. Geochem Geophys Geosyst 8, Q10009, doi:10.1029/2007GC001694

> Oliver MJ, Irwin A, Moline MA, Fraser WR, Patterson D, Schofield O, Kohut J (2013) Adélie penguin foraging location predicted by tidal regime switching. PLoS ONE 8:e55163

Peck LS, Barnes DK, Cook AJ, Fleming AH, Clarke A (2010) Negative feedback in the cold: ice retreat produces new carbon sinks in Antarctica. Glob Change Biol 16: 2614-2623

Petrou K, Ralph PJ (2011) Photosynthesis and net primary productivity in three Antarctic diatoms: possible significance for their distribution in the Antarctic marine ecosystem. Mar Ecol Prog Ser 437:27-40

Popels LC, Hutchins DA (2002) Factors affecting dark survival of the brown tide alga Aureococcus anophagerrerens (Pelagophyceae). J Phycol 38:738-744

Pörtner HO, Peck L, Somero G (2007) Thermal limits and adaptation in marine Antarctic ectotherms: an integrative view. Philos Trans R Soc Lond B Biol Sci 362: 2233-2258

Prézelin BB, Hofmann EE, Mengelt C, Klinck JM (2000) The linkage between Upper Circumpolar Deep Water (UCDW) and phytoplankton assemblages on the west Antarctic Peninsula continental shelf. J Mar Res 58: 165-202

Prézelin BB, Hofmann EE, Moline M, Klinck JM (2004) Physical forcing of phytoplankton community structure and primary production in continental shelf waters of the Western Antarctic Peninsula. J Mar Res 62:419-460

> Ryan JP, Chavez FP, Bellingham JG (2005) Physical-biological coupling in Monterey Bay, California: topographic influences on phytoplankton ecology. Mar Ecol Prog Ser 287:23-32

Sailley SF, Ducklow HW, Moeller HV, Fraser WR and others (2013) Carbon fluxes and pelagic ecosystem dynamics near two western Antarctic Peninsula Adélie penguin colonies: an inverse model approach. Mar Ecol Prog Ser 492:253-272

Schofield OM, Ducklow H, Bernard KS, Doney SC and others (2013) Penguin biogeography along the West Antarctic Peninsula: testing the canyon hypothesis with Palmer LTER observations. Oceanography 26:204-206

Serebrennikova YM, Fanning KA (2004) Nutrients in the Southern Ocean GLOBEC region: variation, water circulation, and cycling. Deep-Sea Res II 51:1981-2002

Shevenell AE, Kennett JP (2002) Antarctic Holocene climate change: a benthic foraminiferal stable isotope record from Palmer Deep. Paleoceanography 17:9.1-9.12

Smayda TJ, Mitchell-Innes B (1974) Dark survival of autotrophic, planktonic marine diatoms. Mar Biol 25:195-202

Smith R, Baker KS, Byers M, Stammerjohn SE (1998) Primary productivity of the Palmer Long Term Ecological Research Area and the Southern Ocean. J Mar Syst 17: 245-259

Smith RC, Martinson DG, Stammerjohn SE, Iannuzzi Ra, 
Ireson K (2008) Bellingshausen and western Antarctic Peninsula region: pigment biomass and sea ice spatial/temporal distributions and interannual variabilty. Deep-Sea Res II 55:1949-1963

> St-Laurent P, Klinck JM, Dinniman MS (2013) On the role of coastal troughs in the circulation of warm circumpolar deep water on Antarctic shelves. J Phys Oceanogr 43: 51-64

Stammerjohn SE, Martinson DG, Smith RC, Iannuzzi RA (2008) Sea ice in the western Antarctic Peninsula region: Spatio-temporal variability from ecological and climate change perspectives. Deep-Sea Res II 55:2041-2058

Stammerjohn S, Massom R, Rind D, Martinson D (2012) Regions of rapid sea ice change: an inter hemispheric seasonal comparison. Geophys Res Lett 39:L06501, doi: 10.1029/2012GL050874

Trenberth KE, Jones PD, Ambenje P, Bojariu R and others (2007) Observations: surface and atmospheric climate change. In: Solomon S, Qin D, Manning M, Chen Z, Marquis M, Averyt KB, Tignor M, Miller HL (eds) Climate change 2007: the physical science basis. Contribution of Working Group I to the Fourth Assessment Report of the Intergovernmental Panel on Climate Change. Cambridge University Press, Cambridge, p 235-336

> Turner J, Maksym T, Phillips T, Marshall GJ, Meredith MP (2012) The impact of changes in sea ice advance on the large winter warming on the western Antarctic Peninsula. Int J Climatol 33:852-861

Vaillancourt RD, Brown CW, Guillard RR, Balch WM (2004) Light backscattering properties of marine phytoplankton: relationships to cell size, chemical composition and taxonomy. J Plankton Res 26:191-212

- Vaughan DG (2006) Recent trends in melting conditions on the Antarctic Peninsula and their implications for ice- sheet mass balance and sea level. Arct Antarct Alp Res 38:147-152

Vaughan DG, Marshall GJ, Connolley WM, Parkinson C and others (2003) Recent rapid regional climate warming on the Antarctic Peninsula. Clim Change 60:243-274

Vernet M, Martinson D, Iannuzzi R, Stammerjohn S and others (2008) Primary production within the sea ice zone west of the Antarctic Peninsula: I-Sea ice, summer mixed layer, and irradiance. Deep-Sea Res II 55:2068-2085

- Wallace MI, Meredith MP, Brandon MA, Sherwin TJ, Dale A, Clarke A (2008) On the characteristics of internal tides and coastal upwelling behaviour in Marguerite Bay, west Antarctic Peninsula. Deep-Sea Res II 55:2023-2040

Warner NR, Domack EW (2002) Millennial- to decadal-scale paleoenvironmental change during the Holocene in the Palmer Deep, Antarctica, as recorded by particle size analysis. Paleoceanography 17:PAL 5-1-PAL5-14

> Wright SW, Jeffrey SW (1987) Fucoxanthin pigment markers of marine phytoplankton analysed by HPLC and HPTLC. Mar Ecol Prog Ser 38:259-266

Wright SW, Jeffrey SW, Mantoura RFC, Llewellyn CA, Bjornland T, Repeta D, Welschmeyer N (1991) Improved HPLC method for the analysis of chlorophylls and carotenoids from marine phytoplankton. Mar Ecol Prog Ser 77:183-196

Xiong X, Sun J, Esposito J, Guenther B, Barnes WL (2002) MODIS reflective solar bands calibration algorithm and on-orbit performance. In: Proceedings of SPIE-Optical Remote Sensing of the Atmosphere and Clouds III, 4891: 95-104

Xiong X, Sun J, Xie X, Barnes WL, Salomonson VV (2010) On-orbit calibration and performance of Aqua MODIS reflective solar bands. IEEE Trans Geosci Remote Sens 48:535-546

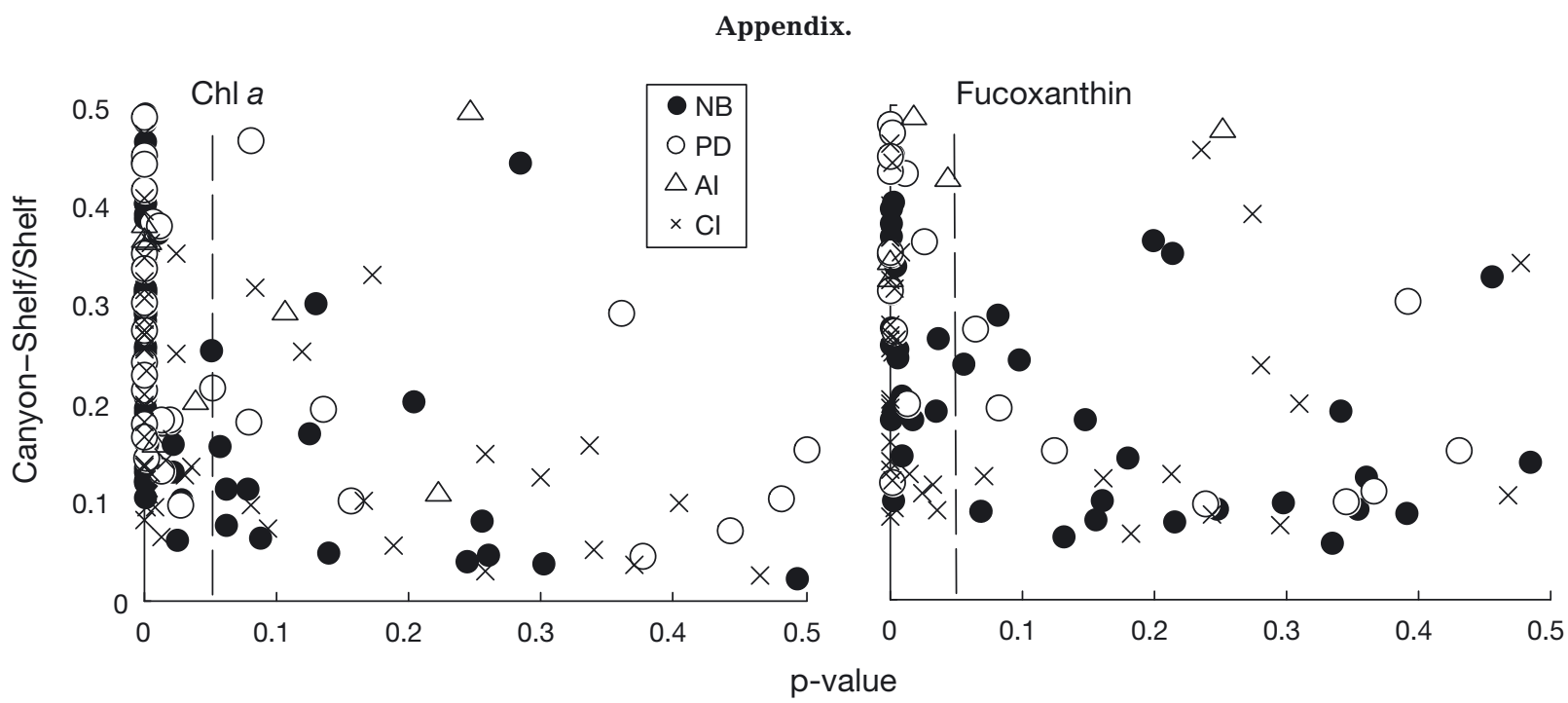

Fig. A1. Minimum detectable difference between canyon and shelf pigment concentrations. Regions are denoted as follows: NB: North Brabant; PD: Palmer Deep; AI: Avian Island; and CI: Charcot Island. Sensitivity is determined as the minimum difference necessary to obtain a significant result (dashed line, $\mathrm{p}<0.05$ ). Significance is determined using 2 -sided $t$-tests comparing pixels of $8 \mathrm{~d}$ composites within the respective polygons

Editorial responsibility: Katherine Richardson, Copenhagen, Denmark
Submitted: April 29, 2014; Accepted: December 30, 2014

Proofs received from author(s): March 5, 2015 